\title{
Pengaruh Kecepatan Pembentukan Tukak Lambung Terhadap Pemberian Berbagai Golongan NSAID Pada Tikus Jantan
}

\section{The Effect Of The Speed Of Gastric Ulcer On The Administration Of Various Classes of NSAID In Male Rats}

\author{
Parhan ${ }^{1)}$ dan Aliman Yafarugi Gulo ${ }^{2)}$ \\ Fakultas Farmasi, Institut Kesehatan Deli Husada Deli Tua, Jalan Besar no. 77 \\ Deli Tua Kab. Deli Serdang 20355, Sumatera Utara, Indonesia \\ Email: alimangulo@yahoo.com,parhanidr@gmail.com \\ DOI: https://doi.org/10.35451/jfm.v1i2.147
}

\begin{abstract}
Gastric ulcer is wound to the mucosal layer (epithelial layer) of the stomach and mucosal irritation of $5 \mathrm{~mm}$ or more in diameter with depth down to submucosa. The basic pathogenesis of gastric ulcers in when there is an imbalance of aggressive factor enhancement. Non-steroidal antiinflammantory drug can cause stomach ulcers in two ways, either directly or topical irritation of the epithelial tissue and inhibit the endogeneous system of gastrointestinal mucosa of prostaglandins. In this case inhibition of prostaglandin systhesis is the dominant factor of peptic ulcers by NSAIDs. The purpose of this study was to determine the effct of NSAID drug administration on the formation of peptic ulcers and to know the difference in the rate of formation of peptic ulcers from each class. Sampel method mice performed surgery on the stomach is done in Pharmacology Laboratory of Pharmacy Institute Deli Husada Deli Tua.The results of this study indicate that faster drugs cause gastric ulcers with a degree of redness are Aspirin $4.03 \mathrm{~mm}, 2.01 \mathrm{~mm}$ mefenamat and $1.02 \mathrm{~mm}$. The results of this study it can be concluded that Aspirin administration with doses of $21 \mathrm{mg} / \mathrm{kg}$ faster causes gastric ulcers from other NSAID groups such as Mefenamat with a dose of $21 \mathrm{mg} / \mathrm{kg} \mathrm{BW}$, Diclofenac sodium at a dose of $2 \mathrm{mg} / \mathrm{kg}$ while administration, Ibuprofen for ten days does not couse ulcers in the stomach of experimetal animals.
\end{abstract}

Keywords : $\quad$ Gastric Ulcer, NSAID, Diclofenac Sodium, Ibuprofen. 


\section{PENDAHULUAN}

Tukak lambung pada waktu sekarang menjadi salah satu penyakit yang banyak diderita masyarakat dan apabila dalam kondisi yang parah dapat menyebabkan kematian. Tukak lambung adalah suatu penyakit yang ditandai dengan rusaknya lapisan mukosa sampai ke lapisan mukosa muskularis. Ketidakseimbangan antara faktor agresif/perusak dan protektif/ pelindung merupakan penginduksi terjadinya tukak lambung. Peningkatan $\mathrm{HCl}$ lambung sebagai faktor agresif adalah kondisi patologis yang terjadi karena produksi $\mathrm{HCl}$ yang tidak terkontrol dari sel-sel parietal di mukosa lambung (Fadlina, dkk., 2008).

Penyakit tukak lambung merupakan lesi pada lapisan mukosa lambung serta terjadi iritasi mukosa dengan diameter $5 \mathrm{~mm}$ atau lebih besar sampai ke lapisan submukosa lambung. Mekanisme terbentuknya tukak lambung ialah apabila adanya ketidakseimbangan antara faktor desensif dan faktor agresif pada mukosa gastroduodenal, terjadinya penurunan daya defensif mukosa dan meningkatnya faktor agresif. Faktor defensif adalah sekresi bikarbonat, mukus, aliran darah pada mukosa lambung, difusi balik ion hidrogen pada epitel dan pembaruan sel epitel lambung. Beberapa yang termasuk faktor agresif adalah $\mathrm{HCl}$ lambung, asam empedu, pepsin, enzim pankreas, infeksi bakteri $H$. Pylori, penggunaan obat golongan non-steroidal anti inflamatory drugs (NSAIDs) dan konsumsi alkohol (Price dan Lorraine, 2006).

Data badan dunia WHO menyatakan bahwa kematian yang terjadi akibat penyakit tukak lambung di Indonesia mencapai angka 0,9\% yang didapatkan dari angka kematian 8,41 setiap seratus ribu jiwa. Pada tahun 2005 sampai 2008, penyakit tukak lambung menduduki peringkat ke-10 dalam kategori kematian pada kelompok umur 45-54 tahun pada laki-laki menurut BPPK Depkes pada tahun 2008. Tingginya angka kematian tersebut disebabkan oleh komplikasi tukak lambung, yaitu perforasi dan pendarahan. Perforasi dapat disebabkan karena konsumsi obat anti inflamasi non steroid (AINS) yang berlebihan (Hill, 2001).

Kasus yang berkaitan dengan kerusakan mukosa lambung yang terjadi di masyarakat seperti dalam kasus tukak lambung dan duodenum, akibat dari efek samping penggunaan non-steroid anti inflammatory drug (NSAIDs), ditandai dengan gejala perut terasa perih/nyeri, mual dan muntah, memiliki prevalensi yang sangat tinggi. Gastritis dan tukak lambung merupakan akibat yang terjadi pada proses inflamasi/peradangan pada lapisan mukosa lambung (Valle, 2001).

Gejala klinik tukak lambung cenderung tidak spesifik pada kasuskasus sederhana. Pemeriksaan laboratorium rutin pun tidak dapat membantu diagnosis tukak lambung yang tidak memiliki komplikasi, sehingga diagnosisnya bergantung pada pemeriksaan radiologi dan endoskopi. Dengan demikian, tukak lambung yang belum memiliki komplikasi sukar didiagnosis (Anand, 2012).

Tukak lambung sering diakibatkan gaya hidup yang tidak baik, seperti pola makan yang buruk, konsumsi NSAID, dan stres. Resiko tukak lambung dan tukak duodenum berkisar antara $11 \%$ $30 \%$ pada pasien dengan asupan NSAID harian. Penelitian pada tahun 1975 menunjukkan bahwa 52\% (32 orang) dari 61 orang dengan tukak lambung mengonsumsi aspirin sebanyak 15 tablet atau lebih dari satu minggu. Aspirin bekerja menghambat sintesis prostaglandin yang bersifat sitoproktektif terhadap mukosa lambung (Sofidiya et al, 2012).

Obat golongan antiinflamasi non steroid dapat menyebabkan luka pada lambung melalui dua cara, yaitu secara langsung atau iritasi topikal dari jaringan epitel dan menghambat sistem endogenous mukosa saluran cerna prostaglandin. Dalam hal ini penghambatan sintesis prostaglandin merupakam faktor dominan penyebab ulkus peptik oleh NSAIDs (Tarigan, 2005). 
Obat NSAID sering digunakan untuk mengatasi rasa sakit, khususnya sakit gigi yang diderita oleh anak. Obat ini merupakan bahan aktif yang secara farmakologi tidak homogen dan terutama bekerja menghambat produksi prostaglandin serta digunakan untuk perawatan nyeri akut dan kronik. Obat ini mempunyai sifat mampu mengurangi nyeri, demam dengan inflamasi, dan yang disertai dengan gangguan inflamasi lainnya (Fajriani, 2008).

\section{Metode Penelitian Sampel}

Sampel yang digunakan dalam penelitian ini adalah Biji Salakyang diperoleh dari Pasar Pusat Kota Medan, Sumatera Utara.

Metode pengambilan sampel dilakukan secara purposif yang dikenal juga sebagai sampling pertimbangan dimana sampel ditentukan atas dasar pertimbangan bahwa sampel yang diambil dapat mewakili populasi atau pengambilan sampel secara sengaja sesuai dengan persyaratan sampel yang diperlukan.

\section{Alat}

Alat yang digunakan dalam penelitian adalah pisau bedah (bistoury), gelas ukur, beker glass, pipet tetes, spuit yang dilengkapi dengan jarum oral sonde, tissue, kapas, gunting, pinset, timbangan hewan, kandang hewan, mikroskop, jangka sorong, kamera, handskun, masker, mortir dan stampher.

\section{Bahan}

Bahan yang digunakan dalam penelitian ini adalah obat-obat golongan NSAID diantaranya yaitu: Aspirin, Ibuprofen, Asam Mefenamat, Natrium Diclofenak, aquabidest, lidocain dan makanan hewan.

\section{Penyiapan Obat}

Obat disiapkan terlebih dahulu, setelah itu ditimbang dan digerus

dengan alat penggerus kemudian diambil dan dilarutkan dengan aquabidest sebanyak $1.25 \mathrm{ml}$, pemberian obat diberikan sesuai berat badan hewan.

\section{Persiapan Hewan Percobaan}

Hewan percobaan yang digunakan adalah tikus putih jantan yang berumur 2-3 bulan dengan berat badan 150-300 gram sebanyak 15 ekor. Sebelum diperlakukan, tikus diaklimatisasi selama 7 hari untuk menyesukan dengan lingkungannya. Selama pemeliharaan, bobot hewan ditimbang dan diamati perilakunya.

Hewan-hewan yang dinilai sehat digunakan dalam percobaan, yaitu bila selama pemeliharaan bobot hewan tetap atau mengalami kenaikan maksimum 10 $\%$ dan menunjukan perilaku yang normal (Vogel, 2002).

\section{Perlakuan Pada Hewan Percobaan}

Hewan percobaan dibagi menjadi 5 kelompok, dimana pengelompokkan hewan coba dilakukan secara acak. Kelompok I merupakan kelompok kontrol dengan Aquabidest. Kelompok II merupakan kelompok uji dengan diberikan obat aspirin melalui oral sebanyak $21 \mathrm{mg} / \mathrm{kgBB}$ selama 10 hari. Kelompok III diberikan obat ibuprofen melalui oral sebanyak $20 \mathrm{mg} / \mathrm{kgBB}$ selama 10 hari. Kelompk IV diberikan obat asam mefenamat melalui oral sebanyak $21 \mathrm{mg} / \mathrm{kgBB}$ selama 10 hari. Kelompok $\mathrm{V}$ diberikan obat natrium diklofenak melalui oral sebanyak 2 $\mathrm{mg} / \mathrm{kgBB}$.

\section{Perlakuan pada kelompok I}

Hewan uji pada kelompok pertama dengan kontrol Aquabidest dilakukan selama 10 hari. Kemudian dilakukan pembedahan untuk mengetahui mukosa lambung hewan. Setelah dibedah, lambung diisolasi untuk dapat mengetahui jumlah dan menghitung indeks tukak dengan menjumlahkan skor yang didapat.

\section{Perlakuan pada kelompok II}

Setiap hewan uji diberikan obat aspirin sebanyak $21 \mathrm{mg} / \mathrm{kgBB} 3 \mathrm{x}$ sehari peroral tanpa dipuasakan dan tetap 
diberi makan tiap hari, kemudian pada hari ke 10 hewan dikorbankan dengan melakukan pembedahan pada bagian abdominal tikus kemudian lambung dikeluarkan. Setelah itu dibedah bagian kurvatora mayor pada lambung tikus. Lambung dibilas dengan aquadest dibentangkan dan selanjutnya diamati mukosa lambung dengan menggunakan mikroskopik, dihitung jumlah dan diukur tukak yang terbentuk pada mukosa lambung tikus kemudian difoto selanjutnya dihitung indeks tukak dengan menjumlahkan skor yang didapat.

\section{Perlakuan pada kelompok III}

Setiap hewan uji diberikan obat ibuprofen sebanyak $20 \mathrm{mg} / \mathrm{kgBB} 3 \mathrm{x}$ sehari peroral tanpa dipuasakan dan tetap diberi makan tiap hari, kemudian pada hari ke 10 hewan dikorbankan dengan melakukan pembedahan pada bagian abdominal tikus kemudian lambung dikeluarkan. Setelah itu dibedah bagian kurvatora mayor pada lambung tikus. Lambung dibilas dengan aquadest dibentangkan dan selanjutnya diamati mukosa lambung dengan menggunakan mikroskopik, dihitung jumlah dan diukur tukak yang terbentuk pada mukosa lambung tikus kemudian difoto selanjutnya dihitung indeks tukak dengan menjumlahkan skor yang didapat.

\section{Perlakuan pada kelompok IV}

Setiap hewan uji diberikan obat asam mefenamat sebanyak $21 \mathrm{mg} / \mathrm{kgBB}$ $3 x$ sehari peroral tanpa dipuasakan dan tetap diberi makan tiap hari, kemudian pada hari ke 10 hewan dikorbankan dengan melakukan pembedahan pada bagian abdominal tikus kemudian lambung dikeluarkan. Setelah itu dibedah bagian kurvatora mayor pada lambung tikus. Lambung dibilas dengan aquadest dibentangkan dan selanjutnya diamati mukosa lambung dengan menggunakan mikroskopik, dihitung jumlah dan diukur tukak yang terbentuk pada mukosa lambung tikus kemudian difoto selanjutnya dihitung indeks tukak dengan menjumlahkan skor yang didapat.

\section{Perlakuan pada kelompok V}

Setiap hewan uji diberikan obat natrium diklofenak sebanyak $2 \mathrm{mg} / \mathrm{kgBB}$ $3 x$ sehari peroral tanpa dipuasakan dan tetap diberi makan tiap hari, kemudian pada hari ke 10 hewan dikorbankan dengan melakukan pembedahan pada bagian abdominal tikus kemudian lambung dikeluarkan. Setelah itu dibedah bagian kurvatora mayor pada lambung tikus. Lambung dibilas dengan aquadest dibentangkan dan selanjutnya diamati mukosa lambung dengan menggunakan mikroskopik, dihitung jumlah dan diukur tukak yang terbentuk pada mukosa lambung tikus kemudian difoto selanjutnya dihitung indeks tukak dengan menjumlahkan skor yang didapat.

\section{Pengukuran Parameter Yang Diamati \\ Lambungyang dibersihkan diamati mukosanya dengan menggunakan alat mikroskop. Ukur diameter tukak dan beri skor berdasarkan keparahan tukak sebagai berikut:}


Tabel 1.Pengamatan indeks tukak lambung.

\begin{tabular}{lll} 
No. & Pengamatan & Skor \\
\hline 1 & Lambung normal & 1 \\
2 & $\begin{array}{l}\text { Lambung kemerahan / } \\
\text { merah }\end{array}$ & 1.5
\end{tabular}

3 Bintik kemerahan atau tukak diameter sampai $0,5 \mathrm{~mm}$ Tukak dengan diameter

4
panjang 0,5-1,5mm Tukak dengan diameter

5 /
panjang 1,6-4mm Tukak dengan diamater

6 /
panjang lebih dari $4 \mathrm{~mm}$ Perforasi dengan

7 diamater / panjang $2-7 \mathrm{~mm}$ Perforasi dengan 8 diameter / panjang 8-13mm Perforasi dengan diameter / panjang lebih dari $13 \mathrm{~mm}$

Keterangan :

$(*) \quad=$ Nilai Yang diberikan disetiap parameter

(n) = Jumlah tukak / perforasi yang ditemukan (wattimena, 2001).

$\mathrm{n} \times 2^{*}$

$\mathrm{n} \times 8^{*}$ est

Normal

Skor $=1$

$190 \mathrm{~g}$ Tukak

$\mathrm{mg} / \mathrm{kg}$

$\mathrm{BB}$

$4.03 \mathrm{~mm}$

Skor

$1 \times 5=5$

$190 \mathrm{~g}$ Tukak

Aspirin $2 \quad 21$

$\mathrm{mg} / \mathrm{kg}$

BB

$4.03 \mathrm{~mm}$

Skor

$1 \times 5=5$

$190 \mathrm{~g}$ Tukak $\mathrm{mg} / \mathrm{kg}$

BB

$4.03 \mathrm{~mm}$

Skor

$1 \times 5=5$

Ibuprofen

$\begin{array}{llll}n \times 5^{*} & 7 & 1 & 20\end{array}$

$\mathrm{mg} / \mathrm{kg}$

BB

Ibuprofen

82

20

$\mathrm{mg} / \mathrm{kg}$

BB

Ibuprofen

93

20

$\mathrm{mg} / \mathrm{kg}$

BB

10 As.

21

Mefenama

t $1 \quad \mathrm{mg} / \mathrm{kg}$

BB

Tabel 2.Lembar Observasi

\begin{tabular}{|c|c|c|c|c|c|c|}
\hline $\begin{array}{l}\mathrm{N} \\
\mathrm{o} .\end{array}$ & Kelompok & Dosis & BB & $\begin{array}{l}\text { Hari } \\
\text { Ke } 10\end{array}$ & $\begin{array}{l}\text { As. } \\
\text { Mefenama } \\
\text { t } 2\end{array}$ & $\begin{array}{l}21 \\
\mathrm{mg} / \mathrm{kg}\end{array}$ \\
\hline 1 & Kontrol 1 & $\begin{array}{l}\text { Aquabid } \\
\text { est }\end{array}$ & $150 \mathrm{~g}$ & $\begin{array}{l}\text { Lambung } \\
\text { Normal }\end{array}$ & & $\mathrm{BB}$ \\
\hline 2 & Kontrol 2 & Aquabid & $150 \mathrm{~g}$ & $\begin{array}{l}\text { Skor=1 } 12 \\
\text { Lambung }\end{array}$ & $\begin{array}{l}\text { As. } \\
\text { Mefenamat }\end{array}$ & 21 \\
\hline & & & & $\begin{array}{l}\text { Normal } \\
\text { Skor=1 }\end{array}$ & 3 & $\begin{array}{l}\mathrm{mg} / \mathrm{kg} \\
\mathrm{BB}\end{array}$ \\
\hline
\end{tabular}

3 Kontrol 3 Aquabid $150 \mathrm{~g}$ Lambung
$2.01 \mathrm{~mm}$

Skor

$1 \times 4=4$

$160 \mathrm{~g}$ Lambung

Normal

Skor $=1$

$160 \mathrm{~g}$ Lambung

Normal

Skor $=1$

$160 \mathrm{~g}$ Lambung

Normal

Skor $=1$

$180 \mathrm{~g}$ Tukak

$180 \mathrm{~g}$ Tukak

$2.01 \mathrm{~mm}$

Skor

$1 \times 4=4$

$180 \mathrm{~g}$ Tukak

$2.01 \mathrm{~mm}$

Skor

$1 \times 4=4$ 
Received: 10 April 2019 :: Accepted: 25 April 2019 :: Published: 29 April 2019

13 Na.

Diclofenak

1

$2 \mathrm{mg} / \mathrm{kg} 160 \mathrm{~g}$ Tukak

BB

$1.02 \mathrm{~mm}$

Skor

$1 \times 3=3$

$14 \mathrm{Na}$.

Diclofenak

2

$2 \mathrm{mg} / \mathrm{kg} 160 \mathrm{~g}$ Tukak

BB

$1.02 \mathrm{~mm}$

Skor

$1 \times 3=3$

$15 \mathrm{Na}$.

$2 \mathrm{mg} / \mathrm{kg} 160 \mathrm{~g}$ Tukak

Diclofenak

3

BB $1.02 \mathrm{~mm}$
Gambar 1. Lambung tikus dengan pemberian obat Aspirin.

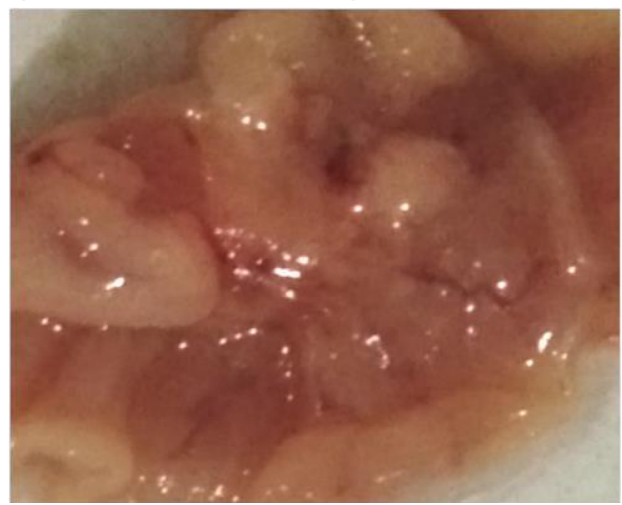

Gambar 2. Lambung tikus dengan pemberian obat Asam Mefenamat Skor $1 \times 3=3$

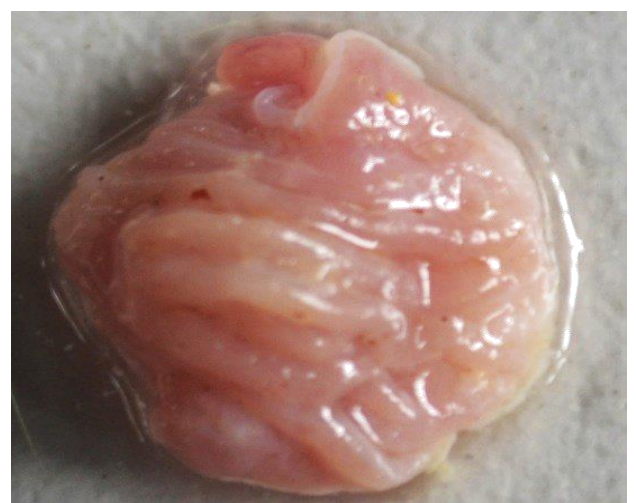

Gambar 3. Lambung tikus dengan pemberian obat Natrium Diclofenak 
Gambar 4. Lambung tikus dengan pemberian obat Ibuprofen

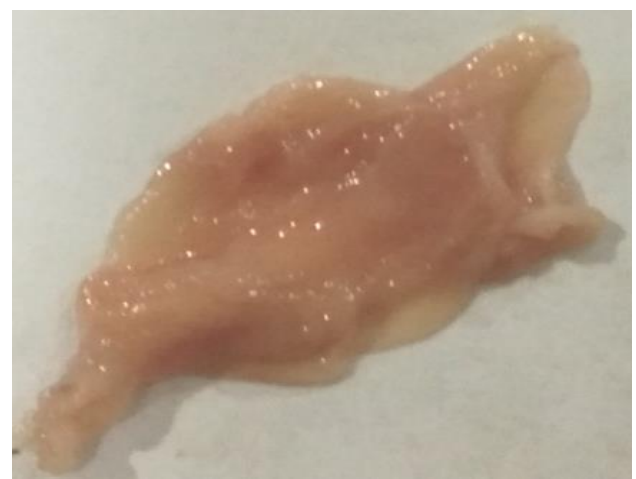

Gambar 5. Lambung tikus dengan perlakuan kontrol

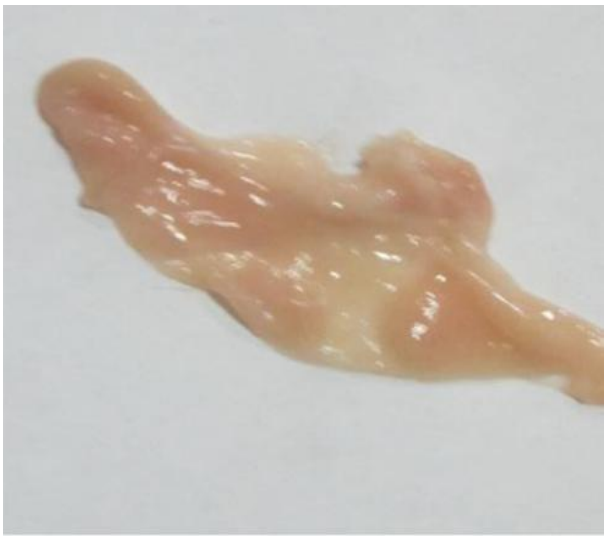

\section{Analisis Data Secara Statistik}

Dari tabel diatas maka dapat disimpulkan bahwa golongan NSAID yang diberikan pada perlakuan memiliki pengaruh yang dapat menyebabkan kecepatan tukak lambung dimana, nilai $P$ $=0,024<a$ a 0,05. Berdasarkan hipotesis penelitian, jika nilai $P$ (probabilitas) $<a$ $(0,05)$ atau $p(0,024)<$ a $(0,05)$ maka Ho ditolak atau dapat disimpulkan bahwa Terdapat Pengaruh Kecepatan Pembentukan Tukak Lambung Terhadap Pemberian Berbagai Golongan NSAID Pada Tikus Jantan.

\section{Hasil}

Hasil dari penelitian ini menunjukkan bahwa obat yang lebih cepat
Setelah dilakukan penelitian untuk mengetahui pengaruh kecepatan pembentukan tukak lambung terhadap pemberian berbagai golongan NSAID maka dilakukan analisis data dengan menggunakan analisis ANOVA dan dilanjutkan dengan uji one way. Analisis statistika ini menggunakan program SPSS (Statistical Product And Service Solution).

Tabel 3. Data Uji Statistika Menggunakan Analisis ANOVA.

ANOVA

\begin{tabular}{|c|c|c|c|c|c|}
\hline \multicolumn{6}{|c|}{ KELOMPOK } \\
\hline & $\begin{array}{l}\text { Sum of } d \\
\text { Squares }\end{array}$ & & $\begin{array}{l}\text { Mean } \\
\text { Square }\end{array}$ & $\mathrm{F}$ & Sig. \\
\hline \multicolumn{5}{|c|}{ Between } & \\
\hline \multicolumn{6}{|l|}{ Groups } \\
\hline \multicolumn{5}{|l|}{ Within } & \\
\hline Groups & & & & & \\
\hline
\end{tabular}

\section{Total 30,00014}

menyebabkan tukak lambung dengan tingkat keperahan adalah Aspirin, Asam Mefenamat dan Natrium Diklofenak sedangkan obat Ibuprofen tidak menyebabkan tukak lambung. Dapat dilihat dari tabel dibawah ini:

Tabel 4. Diameter tingkat pembentukan tukak lambung.

\begin{tabular}{cc}
\hline Kelompok Obat & $\begin{array}{c}\text { Pembentukan } \\
\text { tukak lambung }\end{array}$ \\
\hline Kontrol & Normal \\
Ibuprofen & Normal \\
Natrium Diklofenak & 1,02 \\
Asam Mefenamat & 2,01 \\
Aspirin & 4,03 \\
\hline
\end{tabular}




\section{Keterangan :}

Normal $=$ Tidak terjadi tukak pada lambung.

1.02 = Diameter tukak pada lambung tikus dengan menggunakan obat Na.Diklofenak. 2.01 = Diameter tukak pada lambung tikus dengan menggunakan obat Asam Mefenamat.

4.03 = Diameter tukak pada lambung tikus dengan menggunakan obat Aspirin.

\section{Pembahasan}

Lambung merupakan organ yang berfungsi sebagai tempat penyimpanan dan pencampur makanan sehingga lambung sangat rentan terhadap bahanbahan iritan seperti obat-obat dan alkohol. Hasil penelitian pada kelompok kontrol dan kelompok ibuprofen menunjukkan gambaran lambung normal dan tidak terjadi luka, tetapi pada kelompok aspirin, asam mefenamat dan natrium diklofenak menyebabkan tukak pada lambung.

Aspirin sangat iritatif tetapi yang paling bertahan lama dan merupakan analgetik efektif dengan durasi kerja sekitar 4 jam. Namun lebih dari 50\%

Aspirin merupakan obat AINS non selektif dan bekerja menghambat COX-1 dan mengurangi efek sitoprotektif prostaglandin sehingga dapat menyebabkan efek samping yang serius pada gastrointestinal atas, termasuk perdarahan dan ulserasi (Enaganti, 2006 ; Mok dan Kwan, 2002). Dari penelitian ini membuktikan bahwa aspirin dapat menyebabkan tukak lambung pada hewan percobaan setelah pemberian obst aspirin selama 10 hari.

Efek samping dari asam mefenamat terhadap saluran cerna yang sering timbul adalah diare, diare sampai berdarah dan gejala iritasi terhadap mukosa lambung, selain itu dapat juga menyebabkan eritema kulit, memperhebat gejala asma dan kemungkinan gangguan ginjal (Rianto, 2007). Hal ini terjadi karena asam mefenamat menghambat sintesis prostaglandin sehingga aliran darah pada pasien tidak dapat mentoleransi efek sampingnya (mual, muntah dan nyeri epigastrium). Timbulnya mual, dispepsia, anoreksia, rasa sakit di lambung, flatulen, diare terjadi pada $10-60 \%$ pasien, karena aspirin dapat mengiritasi lambung dan menghambat pertahanan lambung (Johnson et al., 2007).

OAINS merusak mukosa lambung melalui 2 mekanisme yaitu, tropikal dan sistemik. Kerusakan mukosa secara topikal terjadi karena OAINS bersifat asam dan lipofilik, sehingga mempermudah trapping $\mathrm{H}+$ masuk mukosa dan menimbulkan kerusakan (Wallace et al., 1997).

Seperti diketahui prostaglandin merupakan substansi sitoprotektif yang sangat penting bagi mukosa lambung atau sebagai gastroprotektif ( Hansen dan Elliot, 2005). Di dalam lambung COX-1 menghasilkan prostaglandin (PGE2 dan PGI2) yang menstimulasi mukus dan sekresi bikarbonat serta menyebabkan vasodilatasi, suatu aksi yang menjaga mukosa lambung. Bila sintesi PGE2 terhambat maka aliran darah mukosa terganggu dan hilangnya lapisan mukus yang melindungi mukosa lambung.

mukosa lambung berkurang dan menyebabkan hilangnya lapisan mukus yang melindungi mukosa lambung (Rianto, 2007). Sehingga dalam penggunaan asam mefenamat tidak boleh lebih dari 7 hari karena resiko penyebab tukak lambung akan tinggi dan terbukti dari penelitan yang telah dilakukan asam mefenamat positif menyebabkan tukak pada lambung.

Mekanisme kerjanya dari Natrium diklofenak adalah bila membran sel mengalami kerusakan oleh suatu rangsangan kimiawi, fisik, atau mekanis, maka enzim fosfolipase diaktifkan untuk mengubah fosfolipida menjadi asam arachidonat. Asam lemak poli - tak jenuh ini kemudian untuk sebagian diubah oleh enzim cyclo-oksigenase menjadi endoperoksida dan seterusnya menjadi prostaglandin. (Tjay dan Rahardja, 2002).

Diklofenak merupakan obat NSAIDs (Non Steroidal Anti 
Received: 10 April 2019 :: Accepted: 25 April 2019 :: Published: 29 April 2019

Inflammatory Drugs) yang bersifat tidak selektif dimana kedua jenis COX di blokir. Dengan dihambatnya COX-1, dengan demikian tidak ada lagi yang bertanggung jawab melindungi mukosa lambung - usus dan ginjal sehingga terjadi iritasi dan efek toksik pada ginjal (Tjay dan Rahardja, 2002).

Inilah yang menyebabkan meningkatkan tukak lambung pada tikus percobaan setelah menggunakan natrium diklofenak selama 10 hari.

Ibuprofen merupakan golongan obat anti inflamasi non steroid derivat asam propionat yang mempunyai aktivitas analgetik. Mekanisme ibuprofen adalah menghambat isoenzim siklooksigenase-1 dan siklooksigenase-2 dengan cara mengganggu perubahan asam arakidonat menjadi prostaglandin.

\section{KESIMPULAN}

Hasil penelitian dapat disimpulkan bahwa pemberian obat Aspirin dengan dosis $21 \mathrm{mg} \mathrm{/} \mathrm{kg}$ BB lebih cepat menyebabkan tukak pada lambung dari golongan NSAID lain seperti Asam Mefenamat dengan dosis $21 \mathrm{mg} / \mathrm{kg} \mathrm{BB}$, Natrium Diklofenak dengan dosis $2 \mathrm{mg} /$ kg BB sedangkan pemberian Ibuprofen selama sepuluh hari tidak menyebabkan tukak pada lambung hewan percobaan.

\section{Daftar Pustaka}

Anand, B.S., Katz, J., (2012). Peptic Ulcer Disease, Medscape Reference, 
Enaganti, S. 2006, Peptic ulcer disease,The disease and non-drug treatment, Hospital Pharmacist, 3: 239-42.

Fajriani. (2008). Pemberian Obat-obatan Anti Inflamasi Non Steroid (AINS) pada Anak, Indonesian Journal of Dentistry, 15(3): 200-204.

Gan, S., Setiabudy, R., dan Elysabeth, eds. Farmakologi dan Terapi. Edisi 5. Jakarta: Departemen Farmakologi dan Terapeutik FK UI, 237.

Johnson RJ, Kang DH, Feig D, Kivlighn S, Kannelis J, Watanabe S, Tuttle KR (2007). Is there a pathogenetic role for uric acid in hypertension and cardiovascular and renal disease? Hypertension, 41:11831190.

$\begin{gathered}\text { Professor. Department of Internal } \\ \text { Medicine, Division } \\ \text { astroenterology, }\end{gathered}$
$\begin{gathered}\text { Baylor }\end{gathered}$

College of Medicine.

Available

from:http://emedicine.medscape. com/[accessed 15 April 2013].

Tarigan, P., (2009). Tukak Gaster. Dalam:

Sudoyo,

A. W.,

Setiyohadi,

B. Alwi,

I., Simadibrata, M., Setiati, S., (eds). Buku Ajar Ilmu Penyakit Ilmu Dalam Edisi V Jilid I. Jakarta: Pusat Penerbitan IImu Penyakit Dalam.

Tjay dan Rahardja, (2002), Obat-obat Penting, Khasiat, Pengunaaan dan Efek Sampingnya, Edisi $\mathrm{V}$, PT Elex Media omputindo Kelompok Gramedia, Jakarta.

Wilmana, P.F., dan Gan, S., (2007). Analgesik-Antipiretik Analgesik AntiInflamasi Nonsteroid dan Obat Gangguan Sendi Lainnya. 